\title{
BIOMASS OF COARSE WOODY DEBRIS FOLLOWING FIRE AND CLEARCUTTING IN LODGEPOLE PINE FORESTS
}

\author{
DENNIS H. KNIGHT $\downarrow$ DANIEL B. TINKER, \\ BOTANY DEPARTMENT \ UNIVERSITY OF WYOMING \\ LARAMIE
}

In forest ecosystems, the decomposition of coarse woody debris, woody roots, twigs, leaves and micro-organisms is a primary source of mineral soil organic matter. Primary productivity, the accumulation of nutrients, and other important ecosystem processes are largely dependent on the mineral soil organic matter that has developed during hundreds or thousands of years. Large quantities of coarse woody debris are typically produced following natural disturbances such as fires, pest/pathogen outbreaks, and windstorms, and make a significant contribution to the formation of soil organic matter (SOM). In contrast, timber harvesting often removes much of the coarse woody debris (CWD), which could result in a decrease in the quantity and a change in the quality of mineral soil organic matter.

The 1988 fires in Yellowstone National Park continue to provide an excellent opportunity to study the effects of fires of various intensities on ecosystem processes. In addition, the Pelican Creek Fire, which occurred in August, 1996 near the northern end of Yellowstone Lake in the Pelican Creek valley, has given us a chance to study CWD amounts immediately following an intense crown fire.

Ecosystems develop under conditions that are dynamic, but which remain within some range of natural variability. At present, national forest managers are uncertain as to the quantity of CWD which should be left in a stand following timber harvest in order to maintain levels of SOM which are within the range of natural variability. Little empirical data exists which help characterize the range of natural variability with regard to CWD in lodgepole pine forests, and it is therefore difficult to assess current timber harvesting practices in terms of how much CWD should be left at each site. We began a pilot study in late summer of 1995 to begin to address this deficiency. A study of broader scope, based on results from this pilot study, has been underway since that time. This study will attempt to measure specific processes which include the amounts, distribution, decomposition, combustion by natural fires, and removal of CWD in lodgepole pine (Pinus contorta var. latifolia) forests.

The specific objectives of this project are: i) Compare the mass and distribution of coarse woody debris that remains following fires of varying intensities to that which remains following clearcutting in the Rocky Mountain Region; ii) estimate the amount of CWD that is combusted or converted to charcoal following fires of varying intensities in stands of varying stages of development; and iii) estimate the length of time necessary for every square meter of the forest soil to be affected by CWD under natural and managed conditions. 


\section{STUDY AREAS}

Research sites for this project are located in lodgepole pine forests of central and southern Yellowstone National Park in northwestern Wyoming, and in the Medicine Bow National Forest in southeastern Wyoming. All stands selected for sampling were at least 3 ha in size. Sites in the Yellowstone study were selected based on two important criteria: a chronosequence of post-fire ages ranging from 7 - 250 years, located in stands of similar habitat type, and a series of stands which represent the range of burn intensities of the 1988 fires, including unburned stands. Additional study stands were sampled this year to compliment the stands sampled in 1995 and 1996. Clearcut stands in the Medicine Bow National Forest were all harvested between 1991-1993, and were subjected to roller-chopping, a post-harvest slash treatment which fragments and redistributes the slash somewhat evenly around the clearcut. Uncut stands in the Medicine Bow were located as near to the clearcuts as possible, and were chosen to be similar in stand density and age to the pre-harvest characteristics of the clearcuts. The climate and vegetation types between the two regionallyseparated sites are quite similar, and initial analysis of CWD biomass amounts from each study area indicate that reasonable comparisons regarding biomass and cover estimates may be made.

\section{$\downarrow \quad$ FIELD METHODS}

Tree age data, either from tree cores or annual rings on stumps, were used to estimate stand ages and disturbance histories. For all stands in both of the study areas, the following data were obtained: mass (Mg/ha) and percent cover of standing and detrital bolewood and large branch wood by size class, decay class, and approximate time of origin. The biomass estimates for standing live and dead trees and stumps were obtained using the planar intercept method (Brown 1974). Mass of standing dead and live bolewood, woody roots and root crowns was estimated by using allometric equations which utilize bole diameters (Pearson et al.1984). Percent cover of standing and detrital bolewood was calculated from field maps created for at least two $20 \times 20 \mathrm{~m}$ areas in each stand. These maps contained scaled drawings of all dead and downed woody detritus by decay class, all sound and downed woody detritus, and all standing live and dead trees and stumps. Initial sampling was performed in 1995 and 1996 in lodgepole pine stands in the Medicine Bow National Forest, where timber harvesting has occurred for decades. Measurements of standing and downed CWD and woody roots were made in stands of lodgepole pine on sites of similar substrate and at similar elevation in Yellowstone National Park, and these measurements were compared to the Medicine Bow estimates.

During the summer of 1997 we designed a new sampling strategy which will address our second study objective by quantifying the amount of wood consumed by fires of varying intensities, as well as the amount of wood which is converted to charcoal but is still present on the forest floor. The 1996 Pelican Creek fire revealed evidence for the consumption of wood by fire that was not present in older stands that burned during 1988. This evidence was in the form of "log shadows" and unoccupied trenches in the forest floor. The log shadows are apparently created by the intense heat from a burning log slightly elevated above the forest floor, which oxidizes the uppermost layer of the mineral soil, creating a "shadow" of light-colored ash. Trenches are sites formerly occupied by rotting logs, but which were completely consumed during the fire. By mapping these shadows and trenches, we hope to be able to estimate the amount of wood that is burned during an intense crown fire.

We also measured the thickness of charcoal layers on burned logs to estimate the amount of wood that is converted to charcoal, but is still present on the forest floor. When analyzed later this year, these estimates will allow for more accurate predictions of the amounts of CWD which remain following natural fires in lodgepole pine forests.

\section{$\downarrow \quad$ RESULTS AND DISCUSSION}

Initial estimates addressing the first objective regarding CWD biomass comparisons between the two study areas indicate that almost twice as much CWD may remain following intense fires than that which remains following clearcutting. However, much of the larger amounts of CWD remaining following fires is attributed to the large number of dead-standing trees which are not consumed during fires, but are killed and eventually fall to the ground. In fact, there were no differences in CWD of any size class $>7.5 \mathrm{~cm}$ 
between clearcuts and burned stands. It should be noted, however, that harvested stands in this study have only been subjected to a single timber harvest, and the present levels of large, downed bolewood, especially wood inherited from the previous standreplacing fire, would likely decrease following repeated harvesting. Clearcuts usually contain higher amounts of fine woody detritus $<7.5 \mathrm{~cm}$ in diameter than do burned stands, probably due to the post-harvest practice of leaving the majority of the slash on the site to be mechanically scattered and roller chopped, and the fact that most of the small woody material is typically consumed by moderate to severe fires.

When comparing clearcut stands to uncut stands, with the exception of the $8-20 \mathrm{~cm}$ size class of downed woody detritus, there were no significant differences in total downed wood between clearcut and uncut stands.

Notably, one stand in YNP which burned in 1975 and again in 1988 contained significantly less CWD than either clearcuts or stands which only burned a single time, suggesting that fire return interval may be an important controlling factor in CWD dynamics in natural systems. Perhaps more importantly, the post-fire seedling density in this stand is much lower than stands which burned a single time. This suggests that stands which burn twice within a relatively short time may develop into sparse, open forest stands quite unlike the prefire stand structure. No data are yet available for estimating the amount of wood that is consumed or converted to charcoal.

With regard to our third study objective, we are presently digitizing the field study maps which will be used for percent cover calculations, and are developing a spatially-explicit simulation model (DEADWOOD) which, using the digitized maps, will model the dynamics of CWD following disturbances such as fire and timber harvesting over the course of decades to centuries.

\section{$\downarrow \quad$ LITERATURE CITED}

Brown, James K. 1974. Handbook for inventorying downed woody material. USDA Forest Service General Technical Report INT-16. Intermountain Forest and Range Experiment Station. Ogden, UT. 24 pp.

Pearson, J.A., T.J. Fahey, and D.H. Knight. 1984. Biomass and leaf area in contrasting lodgepole pine forests. Can. J. for. Res. 14: 259-265. 